\title{
An Analysis of Mathematical Critical-Thinking Ability: The Impact of DCT (Dialogue Critical Thinking) and Learning Motivation
}

\author{
Zuhan Nahdiyah ${ }^{1,}{ }^{*}$, Netriwati $^{1}$, Dian Anggraini ${ }^{2}$, Fadly Nendra ${ }^{1}$ \\ ${ }^{1}$ Universitas Islam Negeri Raden Intan Lampung, Indonesia \\ 2 Institut Tekhnologi Sumatera, Indonesia
}

\author{
ARTICLE INFO

\section{Article History} \\ Received :02-07-2020 \\ Revised : 25-08-2020 \\ Accepted :06-09-2020 \\ Published :20-09-2020 \\ Keywords: \\ Deep DCT learning; Learning \\ motivation; Mathematical Critical \\ Thinking ability \\ *Correspondence: E-mail: \\ zuhannahdiyah123@gmail.com \\ Doi: \\ $\underline{10.24042 / d j m . v 3 i 3.6799}$
}

\begin{abstract}
The mathematical critical thinking ability is part of a very important mathematical curriculum. The purpose in this study was to analyze the influence of Deep DCT Learning and the motivation to learn from the mathematical critical thinking ability. Research in is a quantitative study with the type of Quasy experimental Design by using post-test only control. Sampling techniques are performed by means of Random Sampling. Data retrieval is done by giving post-Test and poll. The analysis test used is a two way variances analysis (ANAVA). Based on the research results analyzed that: There is an influence between Deep DCT Learning to the mathematical critical thinking ability, there is a high, moderate and low motivation influence on mathematical critical thinking Skills, There is no interaction between Deep DCT Learning and the motivation to learn the ability of critical thinking mathematically.
\end{abstract}

http://ejournal.radenintan.ac.id/index.php/desimal/index

\section{INTRODUCTION}

The 4.0 era development demands a lot of transformation in the world of education, one of which is the mathematical knowledge that must be learned (Thahir et al., 2019). Changes are considered important because mathematical reasoning is important in solving problems, making decisions, providing confidence, analyzing, assuming, and conducting mathematical scientific research (Rosmaiyadi, 2017). also, critical-thinking ability helps students to express their opinions, develop their ideas (Fakhriyah, 2014; Rodiyana, 2015), analyze a problem, and conclude a decision from a problem (Sari, 2015; Sihotang, 2014). Several factors are thought to influence mathematical criticalthinking ability, including subject matter, indicators, learning model, and learning media (Jumaisyaroh et al., 2015; Nadiya et al., 2016).

One of the learning models for critical thinking skills is Deep DCT which prioritizes the ability to have a deep 
dialogue with one another (Alimni, 2017; Sakban, 2015). It relies on the criticalthinking ability to analyze problems so the right decisions could be made (Permatasari \& Setyowati, 2016; Sani, 2019). Other factors affect the process of learning activities called learning motivation. It is said that motivation is characterized by the emergence of feelings (Cleopatra, 2015; Wenty, 2020). In this case, motivation is relevant to psychological, affection, and emotional issues that can determine human behavior (Mayliana \& Sofyan, 2013; Suardana \& Simarmata, 2013). The function of motivation is to encourage humans to act, determine the direction of action, achieve goals, and select which actions to do (Cahyani et al., 2017; Suprihatin, 2015; Tasrim \& Elihami, 2020).

Deep DCT provides reinforcement of learning that is centered on students (Kurniawan, 2019). The advantages of Deep DCT Learning (Noviandari \& Fratiwi, 2018; Untari et al., 2016) includes training the critical-thinking, analyzing several facts. emphasizing on attitude or effective assessment, assessing the personality, emotional, and spiritual, and gaining knowledge and experience.

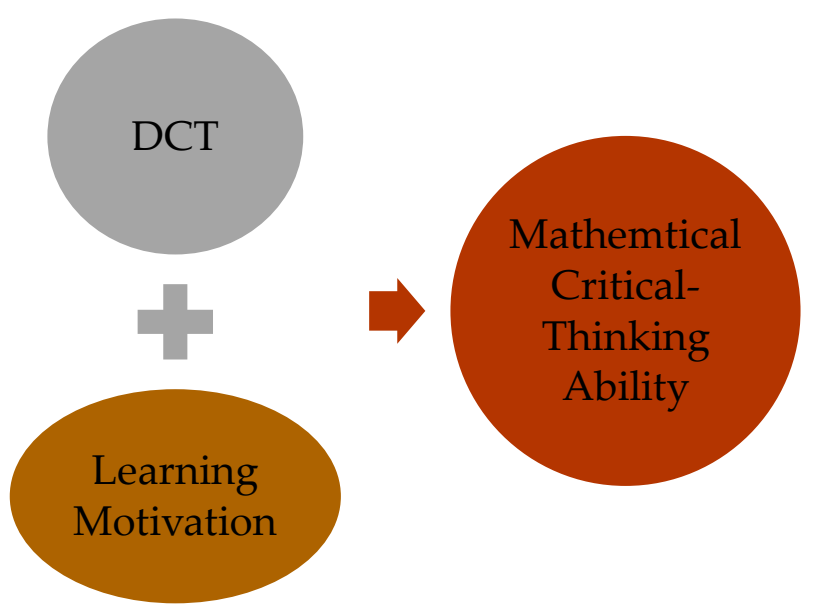

Figure 1. Research Design

The test was used to evaluate Deep DCT learning and the questionnaire was used to measure the learning motivation. The test research instrument trial had met
The Deep DCT learning model on the mathematical critical-thinking ability and the learning motivation can influence the process of learning mathematics to solve problems. This is also supported by several studies on learning motivation (Amiryousefi \& Dastjerdi, 2011). DCT learning influences learning (A'yuni \& Budiwibowo, 2014; Anggreni et al., 2013).

\section{METHOD}

This research was conducted at SMP Negeri 31 Bandar Lampung. The subjects of this research were the tenth-grade students SMP Negeri 31 Bandar Lampung. This research employed the posttest only control group design of quasiexperimental. This study involved two classes, namely the experimental class that applied the Deep DCT learning and the control class that applied conventional learning. After getting the treatment, a posttest was carried out (final test).

The sampling technique used was the cluster random sampling. The data was collected through interviews, documentation, tests, and questionnaires. The instrument used in this research was a written test in the form of essay questions. 
Desimal, 3 (3), 2020 - 221

Zuhan Nahdiyah, Netriwati, Dian Anggraini, Fadly Nendra

RESULTS AND DISCUSSION

Based on Table 1, more students were taught using the Deep DCT learning model than students who were taught using the conventional learning model. The following is the summary of the posttest data of mathematical criticalthinking ability:

Table 1. Data Description of Mathematical Critical-Thinking Ability

\begin{tabular}{lccccccc}
\hline \multicolumn{1}{c}{ Classes } & $\boldsymbol{X}_{\boldsymbol{M a x}}$ & $\boldsymbol{X}_{\text {Min }}$ & \multicolumn{3}{c}{ Central Tendency } & \multicolumn{2}{c}{ Group Variance } \\
& & & $\underline{\boldsymbol{X}}$ & $\boldsymbol{M}_{\boldsymbol{e}}$ & $\boldsymbol{M}_{\boldsymbol{o}}$ & $\boldsymbol{R}$ & $\boldsymbol{S}$ \\
Experimental & 100 & 25 & 66.5 & 67.5 & 64 & 75 & 38.69 \\
Control & 100 & 20 & 48.5 & 40 & 21 & 50 & 91.45 \\
\hline
\end{tabular}

Based on Table 1, the highest score in the experimental class was 100 and the lowest score was 25 . The following is the calculation of two-way ANOVA with unequal cells.

Table 2. The Summary of Two-Way ANOVA with Unequal Cells

\begin{tabular}{cccccc}
\hline Sources & JK & dK & RK & Fobs & F $\boldsymbol{\alpha}$ \\
Learning Method (A) & 965,973 & 1,000 & 965,973 & 4,393 & 4,020 \\
Learning Motivation (B) & 21215,374 & 2 & 10607,787 & 48.24 & 4,020 \\
Interaction (AB) & 161,836 & 2 & 80,918 & 0.368 & 3,168 \\
Error & 11873,754 & 54 & 219,884 & - & - \\
Total & 34217,137 & 59 & - & - & - \\
\hline
\end{tabular}

Based on the data analysis, it was obtained that $F_{a}=4,061>F_{(0,05 ; 1 ; 54)}$. It can be concluded that there were influence differences between students who are taught using the conventional learning model and students' mathematical critical-thinking ability. Also, it was obtained that $F_{b}=101,676>$ $F_{\text {critical }}$. It can be concluded that there were influence differences between students' motivation level and their mathematical critical-thinking ability. It was also obtained that $F_{C}=0,368>$ $F_{\text {tabel }}$ which indicated that there was no interaction between the Deep DCT learning model in terms of learning motivation and mathematical criticalthinking ability.

Table 3. Mean and Marginal Mean

\begin{tabular}{ccccc}
\hline \multirow{2}{*}{ Model } & \multicolumn{3}{c}{ Mathematics Learning Motivation } & \multirow{2}{*}{ Mean } \\
Learning & High & Moderate & Low & Marginal \\
DDCT & 85,231 & 59,583 & 34,400 & 59,738 \\
Conventional & 76,375 & 47,091 & 30,364 & 51,277 \\
Marginal Mean & 80,803 & 53,337 & 32,382 & \\
\hline
\end{tabular}

Based on the marginal mean, it can be concluded that the Deep DCT learning model was better than the conventional learning model. The result of the multiple comparison test can be seen in Table 4 .

Table 4. Multiple Comparison Test Results

\begin{tabular}{cccc}
\hline Interaction & $\boldsymbol{F}_{\text {observed }}$ & $\boldsymbol{F}_{\text {critical }}$ & Description \\
$\mu_{1}$ vs $\mu_{2}$ & 41,16 & 4,019 & $H_{0}$ was rejected \\
$\mu_{1}$ vs $\mu_{3}$ & 13,31 & 4,019 & $H_{0}$ was rejected \\
$\mu_{2}$ vs $\mu_{3}$ & 79,97 & 3,175 & $H_{0}$ was rejected \\
\hline
\end{tabular}


Based on the multiple comparison test between $\mu_{1}$ vs $\mu_{2}$, there were differences between students with high learning motivation and students with moderate learning motivation on mathematical critical-thinking ability. Between $\mu_{2} v s \mu_{3}$, it was found that there were differences between students with moderate learning motivation and students with low learning motivation on mathematical critical-thinking ability. Between $\mu_{1} v s \mu_{3}$, it was found that there were differences between students with high learning motivation and students with low learning motivation on mathematical critical-thinking ability. The steps of the Deep DCT Learning Model consists of:

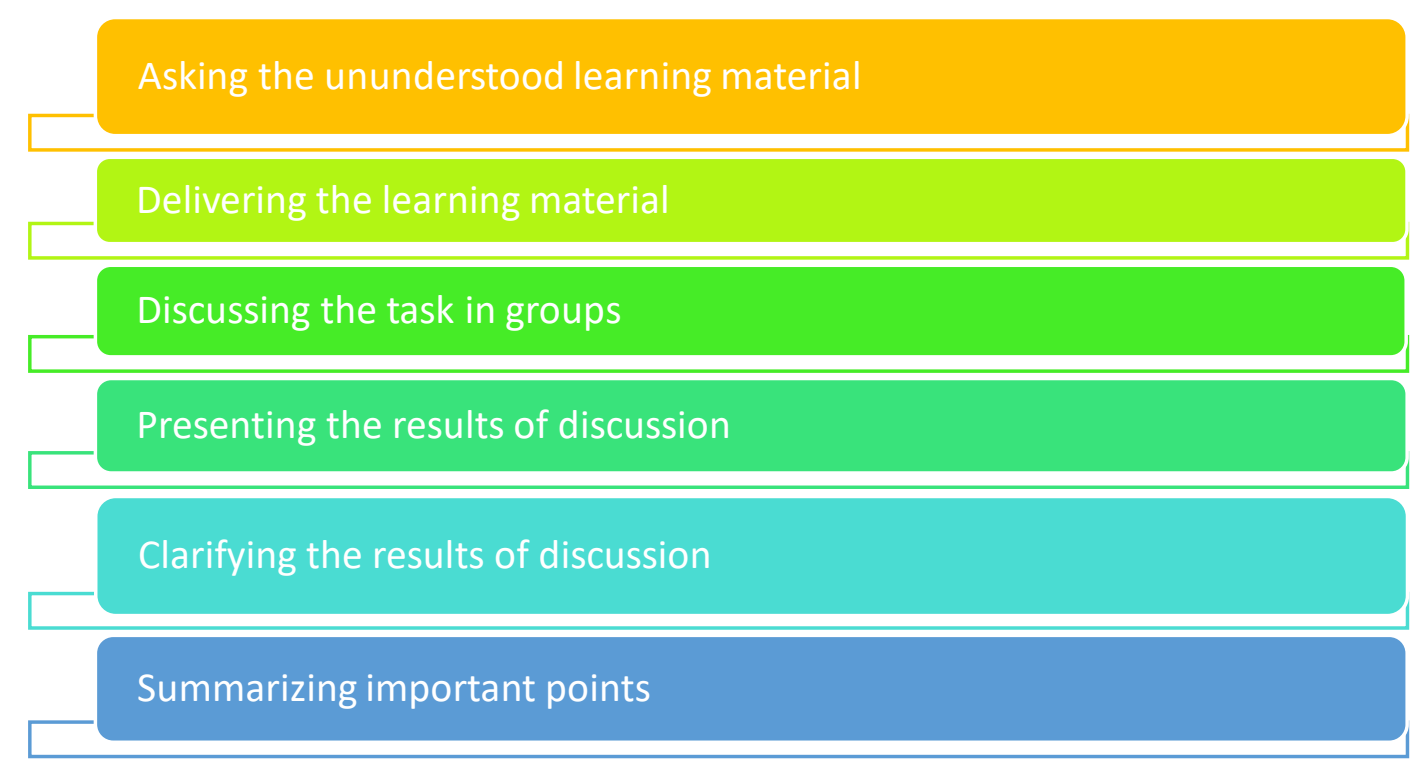

Figure 2. The steps of the Deep DCT Learning Model

The mathematical critical-thinking ability of students who were taught using the Deep DCT learning model was better than the students who were taught using the conventional learning model. Based on the previous theory, it is said that the Deep DCT learning model is one that emphasizes deep dialogue and criticalthinking. Besides, Deep DCT learning can make students have a better criticalthinking ability because they are trained to solve problems related to everyday life. So that they can be more active in the learning process.

The results of the analysis discovered that students with high learning motivation had a better mathematical critical-thinking ability compared to the students with moderate learning motivation. Students with moderate learning motivation had a better mathematical critical-thinking ability compared to students with low learning motivation. There was no interaction between the learning model and learning motivation on mathematical criticalthinking ability.

Based on the results of the two-way ANOVA, it was found that there was no interaction between learning models and learning motivation on students' mathematical critical-thinking ability. This indicated that any learning models applied to the students with high, moderate, or low learning motivation do not have a significant effect on students' mathematical critical-thinking ability. Even though different learning models are applied in each class, the goal remains the same, namely to improve students' mathematical critical-thinking ability.

It is the same as previous research which stated that DCT is quite effective to use. The previous research also analyzed 
that there was a significant influence on Indonesian subject learning outcomes between students who were taught using DCT/critical thinking and students who were taught using conventional learning. The results showed that $t_{\text {observed }}$ was greater than $t_{\text {critical }}(7,897>2,000)$. It was also supported by the difference in the mean score obtained between students who were taught using the Deep DCT learning model (83.32) and students who were taught using conventional learning $(77,42)$. Therefore, the alternative hypothesis was accepted which stated that there was a significant effect of Indonesian learning outcomes between students who are taught using the Deep DCT learning model and students who were taught using conventional learning at the fifthgrade of SD No. 1 Tuban, Kuta District. The previous research had the same results as this research which states that the Deep DCT was effectively used by students to remember the material in a better and more meaningful way. It increased the absorption rate of the learning material and the students' learning outcomes (A'yuni \& Budiwibowo, 2014; Amiryousefi \& Dastjerdi, 2011; Anggreni et al., 2013).

\section{CONCLUSIONS AND SUGGESTIONS}

Based on the results of the analysis and discussion, the mathematical criticalthinking ability of students who were taught using the Deep DCT learning model was better than students who were taught using the conventional learning model. The mathematical critical-thinking ability of students who had moderate mathematics learning motivation was better than students who had low mathematics learning motivation. There was no interaction between learning models and students' motivation for mathematical critical-thinking ability.

Based on the results of the research, it is suggested to use a learning model that makes students more active. Teachers must always develop learning motivation because motivation is an important factor in improving mathematical critical thinking skills. It is hoped for the further researcher to develop this research with other materials and models. Finally, this research is expected to be used as a reference for further research.

\section{REFERENCES}

A'yuni, A. Q., \& Budiwibowo, S. (2014). Pengaruh metode diskusi dengan model pembelajaran DD-CT (deep dialogue-critical thinking) dengan pemberian penguatan terhadap prestasi belajar akuntansi pada siswa kelas XI akuntansi SMKN 1 Geger Madiun. Assets: Jurnal Akuntansi Dan Pendidikan, 3(2), 97-105.

Alimni. (2017). Penerapan pendekatan deepdialogue and critical thingking (Dd\&Ct) untuk meningkatkan mutu proses dan hasil belajar PAI siswa kelas VIII SMPN 20 Kota Bengkulu. Annizom, 2(2), 229-240.

Amiryousefi, M., \& Dastjerdi, H. V. (2011). The relation between MI and motivation and students' likes and dislikes of course books: A comparison between Interchange and Top Notch Elementary books. Procedia-Social and Behavioral Sciences, 30, 1709-1713.

Anggreni, D., Wiyasa, I. K. N., \& Putra, D. K. N. S. (2013). Model pembelajaran deep dealogue/critical thinking berpengaruh terhadap hasil belajar bahasa indonesia siswa kelas V SD No. 1 Tuban Kecamatan Kuta. MIMBAR PGSD Undiksha, 1(1).

Cahyani, N. A. P., Bariyyah, K., \& Latifah, L. (2017). Efektivitas teknik permainan simulasi dengan menggunakan media dart board untuk meningkatkan motivasi belajar siswa kelas VII C SMP Negeri 2 Tegal Siwalan Probolinggo. JKI (Jurnal Konseling Indonesia), 3(1), 22-27.

Cleopatra, M. (2015). Pengaruh gaya hidup dan motivasi belajar terhadap 
prestasi belajar matematika. Formatif: Jurnal Ilmiah Pendidikan MIPA, 5(2).

Fakhriyah. (2014). Penerapan problem based learning dalam upaya mengembangkan kemampuan berpikir kritis mahasiswa. Jurnal Pendidikan IPA Indonesia, 3(1).

Jumaisyaroh, T., Napitupulu, E. E., \& Hasratuddin. (2015). Peningkatan kemampuan berpikir kritis matematis dan kemandirian belajar siswa smp melalui pembelajaran berbasis masalah. Kreano, Jurnal Matematika Kreatif-Inovatif, 5(2), 157-169.

Kurniawan, G. F. (2019). Pembelajaran sejarah di kelas XI SMA semesta bilingual boarding school semarang. Historia Pedagogia, 8(1), 68-75.

Mayliana, E., \& Sofyan, H. (2013). Penerapan accelerated learning dengan pendekatan SAVI untuk meningkatkan motivasi dan hasil belajar kompetensi menggambar busana. Jurnal Pendidikan Vokasi, $3(1)$.

Nadiya, Rosdianto, H., \& Murdani, E. (2016). Penerapan model pembelajaran group investigation (GI) untuk meningkatkan keterampilan berpikir kritis siswa pada materi gerak lurus kelas X. JIPF (Jurnal Ilmu Pendidikan Fisika), 1(2), 49-51.

Noviandari, H., \& Fratiwi, M. E. (2018). Pembelajaran menulis karya ilmiah berbasis deep dialogue/critical thinking. SOSIOEDUKASI: JURNAL ILMIAH ILMU PENDIDIKAN DAN SOSIAL, 7(1), 44-63.

Permatasari, F. I., \& Setyowati, R. N. (2016). Pengaruh model pembelajaran yurisprudensi inkuiri pada mata pelajaran ppkn terhadap peningkatan kemampuan berpikir kritis siswa kelas XI SMAN 1 Wonoayu. Kajian Moral Dan Kewarganegaraan, 3(4), 1500-1514.
Rodiyana, R. (2015). Pengaruh penerapan strategi pembelajaran inkuiri terhadap kemampuan berpikir kritis dan kreatif siswa SD. Jurnal Cakrawala Pendas, 1(1).

Rosmaiyadi. (2017). Analisis kemampuan berpikir kritis matematis siswa dalam learning cycle 7e berdasarkan gaya belajar. AKSIOMA: Jurnal Program Studi Pendidikan Matematika, 6(1), 12-19.

Sakban, A. (2015). Penerapan pendekatan deep dialog and critical thinking terhadap berpikir kritis siswa pada pembelajaran pendidikan kewarganegaraan di SMP Negeri 7 Mataram. Jurnal Ilmiah Mandala Education, 1(2), 121-130.

Sani, L. (2019). Pengaruh penerapan model pembelajaran think talk write terhadap kemampuan berpikir kritis matematis siswa SMP. Al-TA'DIB, 118.

Sari, R. H. N. (2015). Literasi matematika: Apa, mengapa, dan bagaimana. Seminar Nasional Matematika Dan Pendidikan Matematika UNY, 8.

Sihotang, H. T. (2014). Sistem pakar mendiagnosa penyakit kolesterol pada remaja dengan metode certainty factor (Cf) berbasis web. Jurnal Mantik Penusa, 15(1), 16-23.

Suardana, A. A. P. C. P., \& Simarmata, N. (2013). Hubungan antara motivasi belajar dan kecemasan pada siswa kelas VI Sekolah Dasar di Denpasar menjelang Ujian Nasional. Jurnal Psikologi Udayana, 1(1), 203-212.

Suprihatin, S. (2015). Upaya guru dalam meningkatkan motivasi belajar siswa. Jurnal Pendidikan Ekonomi UM Metro, 3(1), 73-82.

Tasrim, \& Elihami. (2020). Motivasi kerja pendidik dalam meningkatkan manajemen lembaga pendidikan dasar. Mahaguru: Jurnal Pendidikan Guru Sekolah Dasar, 1(1), 48-53.

Thahir, A., Komarudin, Hasanah, U. N., \& Rahmahwaty. (2019). Murder 
Desimal, 3 (3), 2020 - 225

Zuhan Nahdiyah, Netriwati, Dian Anggraini, Fadly Nendra

learning and self efficacy models: impact on mathematical reflective thingking ability. Journal for the Education of Gifted Young Scientists, 7(4), 1123-1135.

Untari, S., Hakim, S. Al, \& Astawa, K. D. (2016). Pengembangan model pembelajaran berbasis deep dialogue/critical thinking melalui praktik belajar kewarganegaraan siswa SD di Jawa Timur. Jurnal Ilmiah Pendidikan Pancasila Dan Kewarganegaraan, 23(2).

Wenty, C. S. (2020). Hubungan motivasi kerja dengan kinerja pegawai dinas pendidikan kabupaten pesisir selatan. Jurnal Bahana Manajemen Pendidikan, 3(2), 937-942. 
Desimal, 3 (3), 2020 - 226

Zuhan Nahdiyah, Netriwati, Dian Anggraini, Fadly Nendra 